\title{
PENGGUNAAN ANALISIS PONT PADA POPULASI MAHASISWA SUKU MINANG DI FAKULTAS KEDOKTERAN GIGI UNIVERSITAS ANDALAS
}

\author{
Maya Safitri ${ }^{1}$, Murniwati $^{2}$ \\ ${ }^{1}$ Mahasiswa Fakultas Kedokteran Gigi Universitas Andalas \\ ${ }^{2}$ Staf Fakultas Kedokteran Gigi Universitas Andalas
}

\begin{abstract}
Background: Dental cast analysis is one of the important thing in orthodontic treatments. One of the dental cast analysis which is usually used is Pont analysis, proposed in 1909. Pont did his research to a population in French which is Caucasian and stated that his theory needs to be tested to another ethnics to verify the applicability of Pont analysis to that population. On each race, there are some specific physical characteristics such as the form and width of dentition and dental arch. Minang population are Mongolian who has the different characteristics of dentition and dental arch with the Caucasians. The aim of this study is to identify whether Pont analysis is precise to be used to Minang population. Method : Cross-sectional design was used in this study. This study was done to 65 upper dental casts from Minang student at the Faculty of Dentistry Andalas University who met the inclusion criteria. The difference between the measured and the calculated interpremolar and intermolar arch width was tested with paired $T$ test with the significant value of $0.05(p=0.05)$. Result : Mean value of interpremolar width was $37.8838 \pm 2.29042 \mathrm{~mm}$ and intermolar width was $47.6046 \pm 3.18780 \mathrm{~mm}$. The result of statistical analysis showed that there is no significant differences of the measured and the calculated interpremolar and intermolar width of Minang Student at Faculty of Dentistry Andalas University ( $p>0.05)$. Conclusion : Pont analysis can be used as one of the dental cast analysis in orthodontic diagnosis and treatment planning to Minang population. It is suggested to do a further research to identify lower dental arch form of the Minang population whose upper dental arch width equals to the predicted arch width according to Pont's formula.
\end{abstract}

Keywords : Dental cast analysis, Pont analysis, Minang ethnic

Affiliasi penulis: ${ }^{1}$ Mahasiswa Fakultas

Kedokteran Gigi Universitas Andalas

Korespondensi: Maya Safitri email: safitrimaya18@gmail.com

\section{PENDAHULUAN}

Gigi geligi yang mengalami maloklusi seperti crowding dapat meningkatkan risiko kejadian penyakit periodontal. Hal ini disebabkan oleh sulitnya menjaga oral hygiene karena untuk menghilangkan plak dibutuhkan metode khusus dan waktu yang lebih lama (Madlena, 2012). Dari hasil penelitian yang dilakukan oleh Pugaca et al (2007) diketahui terdapat hubungan antara tingkat keparahan crowding dengan tingkat kejadian penyakit periodontal.

Derajat keparahan crowding dapat diukur dari perbedaan antara ruang yang tersedia pada lengkung rahang dengan jumlah ruang yang dibutuhkan untuk menampung gigi geligi dan untuk melakukan pengukuran ini butuhkan model studi (Johal et al, 2007). Model studi yang merupakan hasil pencetakan rahang merupakan satu-satunya catatan 
tiga dimensi yang non invasiv yang dapat membantu dalam diagnosis dan rencana perawatan untuk kasus ringan maupun berat. Analisis model studi digunakan untuk mengevaluasi kesimetrisan rahang dan susunan gigi geligi jika terjadi crowding (gigi berjejal) atau spacing (diastema) (Wong et al, 2006).

Terdapat berbagai macam jenis analisis model studi yang digunakan dalam diagnosis dan rencana perawatan crowding. Salah satu metode yang digunakan adalah analisis Pont (1909). Menurut Pont, lebar lengkung rahang atas ideal pada regio interpremolar dan intermolar dapat ditentukan dengan membandingkan jumlah lebar mesiodistal keempat gigi insisivus rahang atas dengan suatu nilai konstanta. Lebar lengkung rahang atas ideal pada regio interpremolar ditentukan dengan membandingkan jumlah lebar mesiodistal keempat gigi insisivus rahang atas dengan 0.8. Sedangkan untuk menentukan lebar lengkung rahang atas ideal pada regio intermolar dengan cara yang sama, nilai konstanta yang digunakan adalah 0.64 (Al-Omari et al, 2007).

Pont melakukan penelitian pada populasi di Perancis. Pont menyatakan penelitiannya harus diuji pada kelompok etnis yang berbeda untuk verifikasi dan perbaikan karena terdapat variasi pada ukuran dan bentuk gigi geligi dan lengkung rahang pada setiap ras (Celebi et al, 2011; Poosti, 2007). Analisis Pont digunakan untuk menentukan lebar lengkung ideal yang dibutuhkan untuk menampung seluruh gigi geligi agar didapatkan hasil perawatan ortodonti yang stabil (Celebi et al, 2011; Proffit et al, 2007). Reliabilitas analisis Pont yang tidak baik pada populasi tertentu akan menyebabkan kesalahan dalam rencana perawatan ortodonti untuk mengoreksi crowding dan dapat mengakibatkan terjadinya kegagalan perawatan.

Beberapa penelitian telah menguji analisis Pont pada beberapa populasi yang berbeda. Penelitian pada Suku Jawa yang dilakukan oleh Paramesthi dkk. (2010), populasi Tumkur oleh Sridharan et al (2011), populasi di Yordania oleh Al-Omari et al (2007), dan penelitian pada populasi di Turki oleh Celebi et al (2011). Penelitian tersebut menunjukkan hasil yang berbeda-beda.

Sampel yang digunakan Pont dalam penelitiannya berasal dari ras Kaukasoid yang memiliki tipe lengkung rahang berbentuk huruf "V" yang sempit dengan gigi anterior yang berbentuk seperti pahat. Suku Minang yang tergolong ke dalam ras Mongoloid memiliki lengkung rahang yang berbentuk parabola dan gigi 
anterior yang lebar (Paramesthi dkk, 2010; Yacoob et al, 1996). Mahasiswa Fakultas Kedokteran Gigi Universitas Andalas $70.3 \%$ berasal dari Suku Minang. Berdasarkan alasan - alasan tersebut di atas, dengan demikian peneliti tertarik untuk meneliti bagaimana hasil analisis Pont pada mahasiswa suku Minang di Fakultas Kedokteran Gigi Universitas Andalas

\section{MATERI DAN METODE}

Kajian dalam penelitian ini mencakup pengukuran diskrepansi rahang menggunakan analisis Pont. Kajian ini menggunakan rancangan penelitian analitik dengan metode cross sectional. Pengambilan sampel dilakukan dengan metode Slovin dengan jumlah sampek sebanyak 65 model rahang atas dan rahang bawah mahasiswa Fakultas Kedokteran Gigi Universitas Andalas.

\section{Data Primer}

Data primer diperoleh dari pengukuran model kerja sampel yang terdiri dari variable independen (lebar lengkung interpremolar dan lebar lengkung intermolar) dan variabel dependen (hasil analisis Pont).

\section{Data Sekunder}

Data sekunder diperoleh dari pencatatan dan pelaporan jumlah mahasiswa di Fakultas Kedokteran Gigi Universitas Andalas dan jumlah populasi mahasiswa Suku Minang di Fakultas Kedokteran Gigi Universitas Andalas.

\section{Analisis Data}

1. Analisis Univariat

Analisis univariat dilakukan untuk melihat distribusi frekuensi dari masingmasing variabel independen (jumlah lebar mesiodistal gigi insisivus rahang atas, lebar lengkung interpremolar dan lebar lengkung intermolar) pada mahasiswa Suku Minang di Fakultas Kedokteran Universitas Andalas. Data disajikan secara deskriptif dan dalam bentuk tabel distribusi frekuensi.

2. Analisis Bivariat

Analisis data dilakukan dengan uji-T berpasangan (paired $t$-test) untuk mengetahui perbedaan antara rerata lebar lengkung interpremolar dan rerata lebar lengkung intermolar yang diukur dari model kerja mahasiswa Suku Minang di Fakultas Kedokteran Gigi Universitas Andalas dengan rerata lebar lengkung interpremolar dan rerata lebar lengkung intermolar yang dihitung berdasarkan rumus yang ditetapkan oleh Pont (CPV dan CMV). Jika pada hasil analisis didapatkan nilai kemaknaan lebih kecil dari $0.05 \quad(p<0.05)$ maka terdapat perbedaan bermakna antara rerata lebar lengkung rahang interpremolar dan intermolar yang diukur pada model kerja 
mahasiswa Suku Minang di Fakultas Kedokteran Gigi Universitas Andalas dengan lebar lengkung rahang interpremolar dan intermolar ideal yang dihitung dengan rumus Pont sehingga analisis Pont tidak valid untuk digunakan pada mahasiswa Suku Minang di Fakultas Kedokteran Gigi Universitas Andalas. Jika pada hasil analisis didapatkan nilai kemaknaan lebih besar dari $0.05(p>0.05)$ maka tidak terdapat perbedaan bermakna antara rerata lebar lengkung rahang interpremolar dan intermolar yang diukur pada model kerja mahasiswa Suku Minang di Fakultas Kedokteran Gigi Universitas Andalas dengan lebar lengkung rahang interpremolar dan intermolar ideal yang dihitung dengan rumus Pont sehingga analisis Pont valid untuk digunakan pada mahasiswa Suku Minang di Fakultas Kedokteran Gigi Universitas Andalas.

\section{HASIL PENELITIAN}

\section{Karakteristik Responden}

\section{Umur Responden}

Pada penelitian ini, rentang umur responden adalah 17 tahun sampai dengan 23 tahun. Umumnya responden berumur 18 tahun sebanyak $31 \%$.

Distribusi umur responden pada penelitian ini dapat dilihat pada tabel 3.1

\begin{tabular}{ccc}
\hline $\begin{array}{c}\text { Umur } \\
\text { (tahun) }\end{array}$ & Frekuensi & $\begin{array}{c}\text { Persentase } \\
(\%)\end{array}$ \\
\hline 17 & 3 & 4.6 \\
18 & 20 & 30.8 \\
19 & 12 & 18.5 \\
20 & 13 & 20 \\
21 & 12 & 18.5 \\
22 & 4 & 6.2 \\
23 & 1 & 1.5 \\
\hline Tabel 3.1. & Distribusi & responden \\
berdasarkan umur &
\end{tabular}

\section{Hasil Analisis Univariat}

Lebar Lengkung Interpremolar Diukur

Distribusi rata-rata lebar lengkung interpremolar yang diukur pada model rahang atas mahasiswa suku Minang Fakultas Kedokteran Gigi Universitas Andalas dapat dilihat pada tabel 3.2. berikut

Lebar Lengkung Interpremolar Diukur

\begin{tabular}{lc}
\hline Mean $(\mathrm{mm})$ & 37.8838 \\
Standar & 2.29042 \\
Deviasi (mm) & \\
Min (mm) & 31 \\
Maks (mm) & 42.2 \\
n & 65
\end{tabular}

Tabel 3.2. Distribusi Rata-Rata Lebar Lengkung Interpremolar Diukur Berdasarkan tabel 3.2. diketahui lbahwa rata-rata dari lebar lengkung interpremolar yang diukur pada model rahang atas mahasiswa suku Minang di 
Fakultas Kedokteran Gigi Universitas Andalas adalah $37.8838 \pm 2.29042 \mathrm{~mm}$. Nilai lebar lengkung interpremolar terkecil yang diukur dari model rahang atas adalah $31 \mathrm{~mm}$ sedangkan nilai terbesarnya adalah $42.2 \mathrm{~mm}$.

\section{Lebar Lengkung Interpremolar Dihitung}

Distribusi rata-rata lebar lengkung interpremolar rahang atas mahasiswa suku Minang Fakultas Kedokteran Gigi Universitas Andalas yang dihitung dengan rumus Pont dapat dilihat pada tabel 3.3. berikut

\begin{tabular}{lc}
\hline & $\begin{array}{c}\text { Lebar Lengkung } \\
\text { Interpremolar } \\
\text { Dihitung }\end{array}$ \\
& 37.8981 \\
Mean (mm) & 1.99840 \\
Standar & \\
Deviasi (mm) & 33.25 \\
Min (mm) & 42.63 \\
Maks (mm) & 65 \\
$\mathrm{~N}$ &
\end{tabular}

Tabel 3.3. Distribusi Rata-Rata Lebar Lengkung Interpremolar Dihitung

Berdasarkan tabel 3.3. dapat dilihat bahwa rata-rata lebar lengkung interpremolar yang rahang atas mahasiswa suku Minang di Fakultas Kedokteran Gigi Universitas Andalas yang dihitung dengan rumus Pont adalah $37.8981 \pm 1.99840 \mathrm{~mm}$. Nilai terkecil dari lebar lengkung interpremolar yang dihitung dengan rumus pont adalah 33.25 $\mathrm{mm}$ dan nilai terbesarnya adalah 42.63 $\mathrm{mm}$.

\section{Perbedaan Lebar Lengkung} Interpremolar Diukur dengan Lebar Lengkung Intermolar Dihitung

Perbedaan antara lebar lengkung interpremolar yang diukur pada model rahang atas dengan lebar lengkung interpremolar yang dihitung dengan rumus Pont pada mahasiswa Suku Minang di Fakultas Kedokteran Gigi Universitas Andalas dapat dilihat pada tabel 3.4. berikut.

\begin{tabular}{cc}
\hline & Persentase $(\%)$ \\
\hline Lebih Besar & 49.2 \\
Lebih Kecil & 50.8 \\
$\pm 1 \mathrm{~mm}$ & 52.3
\end{tabular}

Tabel 3.4. Persentase Perbedaan Lebar Lengkung Interpremolar Diukur dengan Lebar Lengkung Interpremolar Dihitung

Pada tabel 3.4. dapat dilihat bahwa $52.3 \%$ dari 65 responden memiliki lebar lengkung interpremolar yang diukur pada model besarnya $\pm 1 \mathrm{~mm}$ dari lebar lengkung interpremolar yang dihitung dengan rumus Pont. Sedangkan 49.2\% dari 65 responden memiliki lebar lengkung interpremolar yang lebih besar daripada lebar lengkung interpremolar yang dihitung dengan rumus Pont dan $50.8 \%$ memiliki lebar lengkung interpremolar yang lebih kecil daripada 
lebar lengkung interpremolar yang dihitung dengan rumus Pont.

\section{Lebar Lengkung Intermolar Diukur}

Distribusi rata-rata lebar lengkung intermolar yang diukur pada model rahang atas mahasiswa suku Minang Fakultas Kedokteran Gigi Universitas Andalas dapat dilihat pada tabel 3.5. berikut

\begin{tabular}{lc}
\hline & $\begin{array}{c}\text { Lebar Lengkung } \\
\text { Intermolar Diukur }\end{array}$ \\
\hline Mean (mm) & 47.6046 \\
Standar & 3.18780 \\
Deviasi (mm) & \\
Min (mm) & 40 \\
Maks (mm) & 54 \\
$\mathrm{n}$ & 65 \\
\hline
\end{tabular}

Tabel 3.5. Distribusi Rata-Rata Lebar Lengkung Intermolar Diukur

Berdasarkan tabel 3.5. dapat dilihat bahwa rata-rata lebar lengkung interpremolar yang rahang atas mahasiswa suku Minang di Fakultas Kedokteran Gigi Universitas Andalas yang dihitung dengan rumus Pont adalah $47.6046 \pm 3.18780 \mathrm{~mm}$. Nilai terkecil dari lebar lengkung intermolar yang diukur pada model adalah $40 \mathrm{~mm}$ dan nilai terbesarnya adalah $54 \mathrm{~mm}$.

\section{Lebar Lengkung Intermolar Dihitung}

Distribusi rata-rata lebar lengkung intermolar rahang atas mahasiswa suku
Minang Fakultas Kedokteran Gigi Universitas Andalas yang dihitung dengan rumus Pont dapat dilihat pada tabel 3.6. berikut

\section{Lebar Lengkung}

Intermolar Dihitung

Mean (mm) $\quad 47.3726$

Standar 2.49800

Deviasi $(\mathrm{mm})$

$\operatorname{Min}(\mathrm{mm})$ 41.56

Maks (mm)

$\mathrm{n}$ 65

Tabel 3.6. Distribusi Rata-Rata Lebar Lengkung Intermolar Dihitung

Berdasarkan tabel 3.6. dapat dilihat bahwa rata-rata lebar lengkung intermolar yang rahang atas mahasiswa suku Minang di Fakultas Kedokteran Gigi Universitas Andalas yang dihitung dengan rumus Pont adalah 47.3726 \pm $2.49800 \mathrm{~mm}$. Nilai terkecil dari lebar lengkung intermolar yang dihitung dengan rumus Pont adalah $41.56 \mathrm{~mm}$ dan nilai terbesarnya adalah $53.28 \mathrm{~mm}$.

Perbedaan Lebar Lengkung Intermolar Diukur dengan Lebar Lengkung Intermolar Dihitung

Perbedaan antara lebar lengkung intermolar yang diukur pada model rahang atas dengan lebar lengkung intermolar yang dihitung dengan rumus Pont pada mahasiswa Suku Minang di Fakultas Kedokteran Gigi Universitas 
Andalas dapat dilihat pada tabel 3.7. berikut.

\begin{tabular}{cc}
\hline & Persentase $(\%)$ \\
\hline Lebih Besar & 50.8 \\
Lebih Kecil & 49.2 \\
$\pm 1 \mathrm{~mm}$ & 30.8
\end{tabular}

Tabel 3.7. Persentase Perbedaan Lebar Lengkung Intermolar Diukur dengan Lebar Lengkung Intermolar Diukur

Pada tabel 3.7. dapat dilihat bahwa $30.8 \%$ dari 65 responden memiliki lebar lengkung intermolar yang diukur pada model besarnya $\pm 1 \mathrm{~mm}$ dari lebar lengkung intermolar yang dihitung dengan rumus Pont. Sedangkan 50.8\% dari seluruh responden memiliki lebar lengkung intermolar yang lebih besar dari pada lebar lengkung intermolar yang dihitung dengan rumus Pont dan 49.2\% responden memiliki lebar lengkung intermolar yang lebih kecil daripada lebar lengkung yang dihitung dengan rumus Pont.

\section{Hasil Analisis Bivariat}

\section{Hasil Perbandingan Lebar Lengkung Interpremolar}

Hasil perbandingan antara lebar lengkung interpremolar yang diukur pada model rahang atas mahasiswa suku Minang di Fakultas Kedokteran Gigi Universitas Andalas dengan lebar lengkung interpremolar rahang atas mahasiswa suku Minang di Fakultas
Kedokteran Gigi Universitas Andalas yang dihitung dengan rumus Pont dapat dilihat pada tabel 3.8. berikut

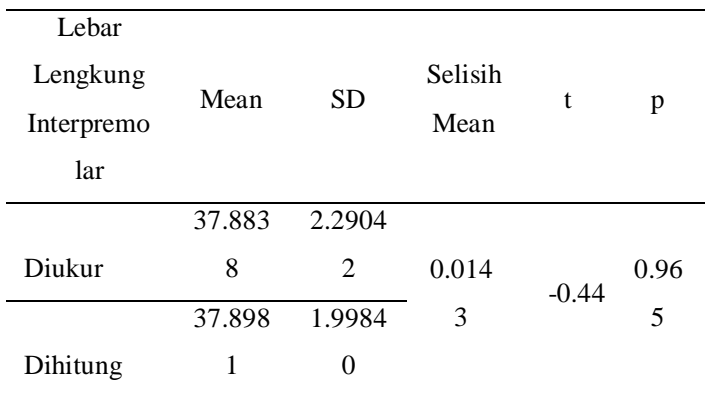

Tabel 3.8. Uji $\mathrm{T}$ Berpasangan Rata-rata Lebar Lengkung Interpremolar Diukur dengan Lebar Lengkung Interpremolar Dihitung

Berdasarkan tabel 3.8. dapat dilihat bahwa terdapat selisih antara lebar lengkung interpremolar yang diukur dengan lebar lengkung interpremolar yang dihitung sebesar 0.0143 dengan nilai $p>0.05 \quad(p=0.965)$, maka dapat disimpulkan bahwa tidak terdapat perbedaan bermakna antara lebar lengkung interpremolar diukur dengan lebar lengkung interpremolar dihitung.

\section{Hasil Perbandingan Lebar Lengkung Intermolar}

Hasil perbandingan antara lebar lengkung intermolar yang diukur pada model rahang atas mahasiswa suku Minang di Fakultas Kedokteran Gigi Universitas Andalas dengan lebar lengkung intermolar rahang atas mahasiswa suku Minang di Fakultas Kedokteran Gigi Universitas Andalas 
yang dihitung dengan rumus Pont dapat dilihat pada tabel 3.9. berikut

\begin{tabular}{lccccc}
\hline $\begin{array}{c}\text { Lebar } \\
\text { Lengkung } \\
\text { Intermolar }\end{array}$ & Mean & SD & $\begin{array}{c}\text { Selisih } \\
\text { Mean }\end{array}$ & $\mathrm{t}$ & $\mathrm{p}$ \\
\cline { 1 - 3 } Diukur & 47.6046 & 3.18780 & 0.232 & -0.54 & 0.591 \\
\cline { 1 - 3 } Dihitung & 47.3726 & 2.49800 & & & \\
\hline
\end{tabular}

Tabel 3.9. Uji $T$ Berpasangan Rata-rata Lebar Lengkung Intermolar Diukur dengan Lebar Lengkung Intermolar Dihitung

Berdasarkan tabel 5.10. dapat dilihat bahwa terdapat selisih antara lebar lengkung intermolar yang diukur dengan lebar lengkung intermolar yang dihitung sebesar 0.232 dengan nilai $\mathrm{p}>0.05$ $(\mathrm{p}=0.591)$, maka dapat disimpulkan bahwa tidak terdapat perbedaan bermakna antara lebar lengkung interpremolar diukur dengan lebar lengkung interpremolar dihitung.

\section{PEMBAHASAN}

Pengujian kembali terhadap analisis Pont telah dilakukan pada beberapa populasi dan etnis yang berbeda untuk menilai reliabilitas dan efektifitas analisis Pont untuk diaplikasikan pada populasi tersebut. Penelitian ini dilakukan pada 65 model rahang atas mahasiswa Suku Minang di Fakultas Kedokteran Gigi Universitas Andalas. Hasil analisis bivariat dengan uji $\mathrm{T}$ berpasangan menunjukkan nilai signifikansi 0.965 $(\mathrm{p}>0.05)$ pada perbandingan antara lebar lengkung interpremolar yang diukur dengan yang dihitung dengan rumus Pont. Sedangkan pada perbandingan lebar lengkung intermolar yang diukur dan yang dihitung dengan rumus Pont adalah $0.591 \quad(p>0.05) \quad$ sehingga dapat disimpulkan tidak terdapat perbedaan yang signifikan antara lebar lengkung interpremolar dan lebar lengkung intermolar yang diukur pada model rahang atas dengan lebar lengkung interpremolar dan lebar lengkung intermolar yang ditentukan dengan rumus Pont. Oleh sebab itu, analisis Pont dapat dipertimbangkan sebagai salah satu analisis model studi yang dapat digunakan dalam melakukan diagnosa dan rencana perawatan ortodonti untuk mengoreksi crowding.

Penelitian yang sebelumnya dilakukan pada suku Jawa oleh Paramesthi (2010) dan pada populasi di Tumkur India oleh Sridharan (2011) menunjukkan hal yang sama. Nilai indeks premolar dan indeks molar pada suku Jawa dan populasi di Tumkur India tidak jauh berbeda dari indeks premolar dan indeks molar yang ditentukan oleh Pont dari populasi Perancis. Sedangkan penelitian yang dilakukan oleh Celebi (2011) pada populasi Turki dan Al-Omari (2007) pada populasi Yordania menunjukkan bahwa lebar lengkung interpremolar dan intermolar yang diukur 
pada model rahang atas populasi tersebut berbeda secara signifikan dengan lebar lengkung interpremolar dan intermolar yang dihitung dengan rumus Pont.

Pada tabel 5.4 dapat disimpulkan $52.3 \%$ dari 65 model rahang atas mahasiswa suku Minang di Fakultas Kedokteran Gigi Universitas Andalas memiliki lebar lengkung interpremolar yang selisih $\pm 1 \mathrm{~mm}$ dari lebar lengkung interpremolar yang dihitung dengan rumus Pont. Hal ini berbeda dengan hasil penelitian Al-Omari (2007) pada populasi di Yordania dan Celebi (2011) pada populasi di Turki. Pada penelitian AlOmari (2007), hanya 29.86\% dari 144 model yang diteliti yang memiliki lebar lengkung interpremolar dengan selisih \pm $1 \mathrm{~mm}$ dengan lebar lengkung interpremolar yang ditentukan dengan rumus Pont. Sementara dari 142 model yang diteliti oleh Celebi (2011), hanya $9.86 \%$ model yang memliki selisih \pm 1 $\mathrm{mm}$ antara lebar lengkung interpremolar yang diukur dengan lebar lengkung interpremolar yang ditentukan dengan rumus Pont.

Sementara pada lengkung intermolar, seperti yang terdapat pada tabel 5.7, hanya 30.8\% dari 65 model yang diteliti memiliki selisih $\pm 1 \mathrm{~mm}$ dari lebar lengkung yang dihitung dengan rumus Pont. Pada populasi di Yordania yang diteliti oleh Al-Omari $24.31 \%$ dari 144 model yang diteliti memiki selisih lebar lengkung intermolar $\pm 1 \mathrm{~mm}$ dari lebar lengkung yang dihitung dengan rumus Pont. Sementara pada populasi di Turki yang diteliti, dari 142 model, $19.72 \%$ yang selisih antara lebar lengkung intermolar diukur dengan lebar lengkung intermolar dihitung $\pm 1 \mathrm{~mm}$. Dari hasil penelitian yang dilakukan pada populasi di Yordania dan Turki yang dilakukan oleh Al-Omari (2007) dan Celebi (2011) dapat disimpulkan bahwa analisis Pont tidak dapat digunakan pada populasi tersebut.

Perbedaan hasil penelitian pada populasi-populasi tersebut disebabkan oleh adanya variasi ciri fisik pada masing-masing populasi tersebut. Salah satu faktor yang menyebabkan terjadinya variasi ciri fisik tersebut adalah faktor genetik. Menurut antropologis, proses adaptasi menyebabkan perubahan struktur genetik yang menyebabkan variasi ciri fisik tersebut. Ciri fisik pada masing-masing populasi tersebut dapat dilihat pada kulit, rambut, bentuk kepala, bentuk wajah, hidung, mata, tinggi badan dan gigi geligi (Yacoob et al, 2006).

Menurut Ripley (1900), populasi Perancis termasuk kepada subras Kaukasoid Alpin yang memiliki wajah yang berbentuk bundar, sedangkan 
populasi Yordania berasal dari subras Kaukasoid Mediterania yang memiliki bentuk wajah oval. Menurut Ricketts (1982) yang dikutip oleh Anwar et al (2010), terdapat hubungan antara tipe wajah dan lengkung rahang sehingga dapat disimpulkan terdapat perbedaan antara bentuk lengkung rahang populasi Perancis dengan populasi Yordania.

Selain itu faktor lingkungan seperti pola makan pada masa pertumbuhan juga dapat mempengaruhi pertumbuhan dan perkembangan rahang yang akan berdampak terhadap bentuk dan ukuran rahang (Yacoob et al, 2006; Sridharan et al, 2011). Pada mamalia, makanan berpengaruh besar terhadap gigi geligi. Perubahan pola gigi geligi pada manusia merupakan akibat dari perubahan fungsional yang disebabkan oleh gaya hidup modern. Terutama perubahan makanan menjadi makanan lunak yang tidak membutuhkan aktivitas mastikasi yang tinggi (Varrela, 2006).

Menurut Corruccini yang dikutip oleh Varrela (2006), perubahan oklusal pada manusia modern disebabkan oleh pertumbuhan rahang yang tidak berlangsung sempurna. Menurutnya, makanan yang berstruktur keras akan membutuhkan mastikasi yang kuat yang kemudian merangsang pertumbuhan tulang-tulang wajah, terutama pertumbuhan maksila dan mandibula secara transversal. Penelitian-penelitian lain menunjukkan bahwa konsistensi makanan tidak hanya mempengaruhi otot-otot mastikasi tetapi juga mempengaruhi pertumbuhan ukuran dan massa tulang, struktur internal tulang, dan ukuran dan morfologi kraniofasial (Varrela, 2006).

Penelitian mengenai analisis Pont dilakukan pada tahun 1909. Rentang waktu selama kurang lebih 100 tahun antara penelitian yang dilakukan oleh Pont dengan penelitian-penelitian pada berbagai populasi termasuk suku Minang, menyebabkan hasil yang berbeda-beda. Pada rentang waktu tersebut tentunya telah terjadi perubahan pola makananan dan distribusi penduduk yang menyebabkan variasi genetik pada satu populasi bertambah.

Analisis Pont tidak mempertimbangkan keadaan lengkung rahang bawah untuk mencapai oklusi yang seimbang (Singh, 2007). Pada penelitian inipun tidak diketahui bagaimana keadaan lengkung rahang bawah sampel penelitian ini. Untuk itu perlu diteliti lebih lanjut lagi mengenai keadaan lengkung rahang bawah responden yang lebar lengkung rahangnya sesuai dengan lebar lengkung yang dihitung dengan rumus Pont. 
Responden penelitian ini terdiri dari 14 orang responden laki-laki dan 51 orang responden perempuan. Dari hasil penelitian ditemukan perbedaan rerata lebar lengkung interpremolar dan intermolar laki-laki dan perempuan. Rerata lebar lengkung interpremolar lakilaki adalah $39.98 \mathrm{~mm}$ dan lebar lengkung interpremolar perempuan adalah 37.58 mm. Sedangkan lebar lengkung intermolar laki-laki adalah $50.41 \mathrm{~mm}$ dan lebar lengkung intermolar perempuan adalah $46.83 \mathrm{~mm}$. Hal ini serupa dengan penelitian Pramanthi (2007) pada maksila dari ras deutro melayu yang ada di bagian anatomi Fakultas Kedokteran Airlangga. Hasil penelitian tersebut menunjukkan bahwa lebar palatum laki-laki lebih besar daripada lebar palatum perempuan yang artinya lebar lengkung rahang laki-laki lebih besar daripada lebar lengkung rahang perempuan. Penelitian oleh Aluko et al (2009) menyimpulkan bahwa lebar lengkung intercaninus, interpremolar dan intermolar laki-laki lebih besar daripada lebar lengkung perempuan.

Pada penelitian yang dilakukan pada populasi di Turki yang terdiri dari 64 model rahang atas laki-laki dan 78 model rahang atas perempuan oleh Celebi (2011) disimpulkan tidak terdapat perbedaan yang signifikan antara lebar lengkung rahang laki-laki dan perempuan. Sedangkan pada penelitian yang dilakukan pada populasi di Yordania yang terdiri dari 71 model rahang atas laki-laki dan 73 model rahang atas perempuan oleh Al-Omari (2007) disimpulkan bahwa lebar lengkung rahang perempuan lebih kecil daripada lebar lengkung rahang laki-laki.

Perbedaan lebar lengkung antara laki-laki dan perempuan disebabkan oleh pertumbuhan maksila secara transversal pada laki-laki berlangsung lebih lama daripada pertumbuhan maksila pada perempuan. Pada perempuan pertumbuhan maksila berhenti pada umur 15 tahun. Sedangkan pertumbuhan maksila pada laki-laki berhenti pada umur 17 tahun sehingga secara transversal lengkung rahang laki-laki lebih lebar daripada lengkung rahang perempuan (Paramesthi, 2010).

$$
\text { Menurut Hakimy }
$$
(1994), masyarakat Minangkabau berasal dari lereng Gunung Merapi. Setelah masyarakat Minangkabau berkembang, penduduk suku Minangkabau berpindah menuruni Gunung Merapi tersebut dan menyebar ke beberapa daerah. Daerah Minangkabau secara garis besar dibagi menjadi 3 daerah yaitu daerah Darek yaitu di sekitar Gunung Merapi, Gunung Sago dan Gunung Singgalang; daerah Pasisia yaitu daerah di sepanjang pantai 
barat pulau Sumatera mulai dari perbatasan daerah Muko Muko Bengkulu sampai perbatasan Tapanuli Selatan; dan daerah Rantau yaitu daerah aliran sungai dan bermuara di sebelah timus pulau Sumatera yang berbatasan dengan Selat Malaka dan Laut Cina Selatan, sampai ke Negeri Sembilan Malaysia.

Pola makanan masyarakat pada berbagai daerah di Minangkabau tersebut tidak berbeda sehingga dapat disimpulkan bahwa tidak ada variasi bentuk lengkung rahang yang ekstrim pada masyarakat suku Minang. Responden dari penelitian ini berasal dari berbagai daerah di Minangkabau dan dapat dinyatakan mewakili masyarakat Minangkabau secara keseluruhan. Akan tetapi sebaiknya dilakukan penelitian dengan jumlah sampel yang lebih besar dengan responden yang berasal dari masing-masing daerah di Minangkabau untuk mendapatkan hasil yang lebih valid.

Penduduk Indonesia terdiri dari berbagai etnis dan suku bangsa. Menurut Pratiwi, distribusi penduduk Indonesia berdasarkan suku bangsa adalah Sunda (14.1\%), Madura (7.1\%), Minang (3.3\%), Bugis (2.5\%), Batak (2.0\%), Bali (1.8\%), 24 suku bangsa lainnya (20.3\%), dan keturunan Cina $(2.7 \%)$. Masing-masing penduduk dari suku bangsa tersebut memiliki ciri yang berbeda-beda. Untuk itu analisis Pont perlu diuji pada populasi dari etnis tersebut.

Selain analisis Pont, untuk mengetahui diskrepansi rahang dapat dilakukan dengan metode analisis lainnya seperti analisis Bolton, analisis Ashley Howe dan Kesling diagnostic set up. Metode-metode tersebut juga perlu diuji pada populasi suku Minang untuk mengetahui aplikabilitas metode analisis tersebut.

\section{KESIMPULAN}

Berdasarkan penelitian yang dilakukan pada mahasiswa suku Minang di Fakultas Kedokteran Gigi Universitas Andalas Padang diperoleh kesimpulan sebagai berikut :

1. Rerata lebar lengkung interpremolar diukur pada model rahang atas mahasiswa suku Minang di Fakultas Kedokteran Gigi Universitas Andalas adalah $37.8838 \pm 2.29042 \mathrm{~mm}$.

2. Rerata Rerata lebar lengkung interpremolar rahang atas mahasiswa suku Minang di Fakultas Kedokteran Gigi Universitas Andalas yang dihitung dengan rumus Pont adalah $37.8981 \pm 1.99840 \mathrm{~mm}$.

3. Rerata lebar lengkung intermolar diukur pada model rahang atas mahasiswa suku Minang di Fakultas 
Kedokteran Gigi Universitas Andalas adalah $47.6046 \pm 3.18780 \mathrm{~mm}$.

4. Rerata Rerata lebar lengkung interpremolar rahang atas mahasiswa suku Minang di Fakultas Kedokteran Gigi Universitas Andalas yang dihitung dengan rumus Pont adalah $47.3726 \pm 2.49800 \mathrm{~mm}$.

5. Tidak terdapat perbedaan bermakna antara lebar lengkung interpremolar yang diukur pada model dengan lebar lengkung interpremolar yang dihitung dengan rumus Pont pada mahasiswa suku Minang di Fakultas Kedokteran Gigi Universitas Andalas.

6. Tidak terdapat perbedaan bermakna antara lebar lengkung intermolar yang diukur pada model dengan lebar lengkung intermolar yang dihitung dengan rumus Pont pada mahasiswa suku Minang di Fakultas Kedokteran Gigi Universitas Andalas.

7. Analisis Pont dapat digunakan pada populasi mahasiswa Suku Minang di Fakultas Kedokteran Gigi Universitas Andalas.

\section{SARAN}

Berdasarkan kesimpulan hasil penelitian, maka peneliti menyampaikan beberapa saran untuk penelitian berikutnya antara lain:

1. Dilakukan penelitian lebih lanjut mengenai hubungan kesesuaian lebar lengkung rahang yang diukur pada model dengan lebar lengkung rahang yang dihitung dengan rumus pont; dengan keadaan lengkung rahang bawah.

2. Dilakukan penelitian lebih lanjut mengenai analisis Pont pada suku Minang dengan jumlah sampel yang lebih besar dan berasal dari setiap daerah di Minangkabau.

3. Dilakukan penelitian untuk menguji aplikabilitas metode analisis model studi lain pada populasi Minang.

4. Dilakukan penelitian lebih lanjut mengenai analisis Pont pada berbagai suku bangsa yang ada di Indonesia karena bangsa Indonesia terdiri dari suku bangsa yang berbeda-beda.

\section{KEPUSTAKAAN}

1. Al-Omari IK, Duaibis DB, Al-Bitar ZB, 2007. Application of Pont's Index to a Jordanian Population. European Journal of Orthodontics. 29 : 627-631

2. Al-Sarraf HA, Abdul-Majwood AA, AlSayagh MM, 2006. Re-Assessment of Pont's Index in Class I Normal Occlusion. Al Rafidain Dental Journal. $6: 1-5$

3. Altemus LA, 1959. Frequency of the Incidence of Malocclusion in American Negro Children Aged Twelve to Sixteen. Angle Orthodontists. 29 : 189-200

4. Aluko IA, daCosta OO, Isiekwe MC, 2009. Dental Arch Widths in the Early and Late Permanent Dentitions of a Nigerian Population. Nig Dent J. 17(1) : 7-11 
5. Anwar N, Fida M, 2010. Variability of Arch Forms in Various Vertical Facial Patterns. Journal of The College of Physicians and Surgeons Pakistan. 20 (9) : 565-570

6. Araujo TM, Fonseca LM, Caldas DL, CostaPinto RA, 2012. Preparation and Evaluation of Orthodontic Set Up. Dental Press J. of Orthodontics. 17 : 146-165

7. Basaran G, Selek M, Hamamci O, Akkus Z, 2006. Intermaxillary Bolton Tooth Size Discrepancies Among Different Malocclusion Group. Angle Orthodontists. 76 : 26-30

8. Bishara SE, 2001. Textbook of Orthodontics. USA : W.B. Saunders Company

9. Blumenfeld J, 2000. Racial Identification in the Skull and Teeth. Totem : The University of western Ontario Journal of Anthropology. $8: 20-32$

10. Brook AH, Griffin RC, Townsen G, Levisianos Y, Russel J, Smiths RN, 2005. Variability and Patterning in Permanent Tooth Size of Four Human Ethnic Groups diunduh dari www.liv.ac.uk

11. Celebi AA, Tan E, Gelgor IE, 2011. Determination and Application of Pont's Index in Turkish Population, The Scientific World Journal 2012

12. Cobourne MT, Di Biase AT, 2010. Handbook of Orthodontics. China : Mosby Elsevier

13. Denton LC, 2011. Shovel-Shaped Incisors and the Morphology of the Enamel-Dentin Junction: an Analysis of Human Upper Incisors in Three Dimensions (Thesis). Colorado State University. p. 18

14. Greenwall L, 2011. Treatment Options for Peg-shaped Laterals Using Direct Composite Bonding. International Dentistry SA. 2(1)
15. Hakimy I, 1994. Pokok Pokok Pengetahuan Adat Alam Minangkabau. Bandung : Remaja Rosdakarya Offset

16. Harty FJ, Ogston R, 1995. Kamus Kedokteran Gigi. diterjemahkan oleh Sumawinata. Jakarta : EGC

17. Hassan R, Rahimah AK, 2007. Occlusion, Malocclusion and Method of Measurement an Overview. Archives of Orofacial Science. $2: 3-9$

18. Hong Q, Koirala R, Jun T, Li-na Y, Takagi S, Kawahara K, Kishimoto E, 2008. A Study About Tooth Size and Arch Width Measurement. Journal of Hard Tissue Biology. 17 : 91-98

19. Johal AS, Battagel JM, 1997. Dental Crowding : a Comparison of Three Methods of Assesment. European Journal of Orthodontics. 19 : 543-551

20. Madlena M, 2012. The Importance and Possibilities of Proper Oral Hygiene in Orthodontic Patients, Orthodontics - Basic Aspects and Clinical Consideration, Bourzgui F (Ed.) diunduh dari http://www.intechopen.com/books/orthodonti cs-basic-aspects-and- clinicalconsiderations/ the-importance-and-possibilities-of-properoral-hygiene-in-orthodontic-patients

21. Miguel-Neto AB, Nishio C, Mucha JN, 2010. Agreement Evaluation of a Newly Proposed System For Malocclusion Classification. Int.

J. Odontostomat. 4(1) : 33-41

22. Mockers O, Aubry M, Mafart B, 2004. Dental Crowding In a Prehistoric Population. European Journal of Orthodontics. $26: 151-156$

23. Nimkarn Y, Miles PG, O'Reilly MT, Weyant RJ. 1995. The Validity of Maxillary 
Expansion Indices. Angle Orthodontists. 65 : 321-326

24. Normando D, Almeida MAO, Quintao CCA, 2012. Dental Crowding - the Role of Genetics and Toothwear. Angle Orthodontists

25. Okeson JP, 2008. Management of Temporomandibular Disorders and Occlusion. USA : Mosby Elsevier

26. Othman SA, Mookin H, Asbolah MA, Hashim NA, 2008. Bolton Tooth-Size Discrepancies Among University of Malaya's Dental Students. Annals of Dentistry University of Malaya. 15 : 40-47

27. Panchal R, 2010. Assessment of Dental Crowding in Mandibular Anterior Region by Three Different Methods. Journal of Dental Science. 2

28. Paramesthi GAMDH, Farmasyanti CA, Karunia D, 2010. Besar Indeks Pont dan Korkhaus Serta Hubungan Antara Lebar dan Panjang Lengkung Gigi terhadap Tinggi Palatum. FKG UGM

29. Petricevic N, Stipetic J, Antonic R, Borcic J, Strujic M, Kovacic I, Celebic A, 2008. Relations Between Anterior Permanent Teeth, Dental Arches and Hard Palate. Coll. Antropol. 32 : 1099-1104

30. Poosti M, Jalali T, 2007. Tooth Size and Arch Size Dimension in Uncrowded Versus Crowded Class I Malocclusion. Journal of Contemporary Dental Practice. 8

31. Pramanthi S, 2007. Perbedaan Ukuran Maxillae dan Mandibulae antara Laki-laki dengan Wanita di Bagian Anatomi Fakultas Kedokteran Universitas Airlangga. Jurnal PDGI. 57 (1) : 26-29

32. Pratiwi PH, Suku Bangsa (Ethnic Group). Pdf diunduh dari http://staff.uny.ac.id/sites/default/files/pendid ikan/Poerwanti\%20Hadi\%20Pratiwi,\%20S.P d.,\%20M.Si./3-PIN-Suku\%20Bangsa.pdf. 2303-2013, 13:19 WIB

33. Proffit WR, Fields Jr HW, Sarver DM, 2007 Contemporary Orthodontics Fourth Edition. Canada : Mosby Elsevier

34. ugaca J, Urtane I, Andra L, Laurina Z, 2007. The Relationship Between the Severity of Malposition of the Frontal Teeth and Periodontal Health in Age 15-21 and 35-44. Baltic Dental and Maxillofacial Journal. 9 : 86-90

35. Ripley WZ, 1900. The Races of Europe : A Sociological Study. London : Kegan Paul, Trench, Trubner \& Co

36. Singh G, 2007 Textbook of Orthodontics. New Delhi : Jaypee Brothers Medical Publisher

37. Sridharan K, Madhusudhan V, Srinivasa H, Mahobia Y, Sailesh S, 2011. Evaluation of Validity of Pont's Index Analysis in Tumkur Population. Journal of Dental Science \& Research. $2: 41-49$

38. Stifter J, 1958. Study of Pont's, Howe's, Rees', Neff's, and Bolton Analyses on Class I Adult Dentition. Angle Orthodontists 28(4) : 215-225

39. Sulandjari H, 2008. Buku Ajar Ortodonsia I KGO I. diunduh dari www.cendrawasih.a.f.staff.ugm.ac.id/wpcontent/buku-ajar-orto-i-th-2008.pdf

40. Varrela J, 2006. Masticary Function and Malocclusion : A Clinical Perspective. Seminars in Orthodontics. 12(2) : 102-109

41. Wong RWK, Hagg U, 2006 The Uses of Orthodontic Study Models in Diagnosis and Treatment Planning. Hong Kong Dental Journal. 3 : 107-115 
42. Yacoob H, Narnbar P, Naidu MDK, 1996.

Racial Characteristic of Human Teeth with

Special Emphasis on the Mongoloid

Dentition. Malaysian J. Pathol. 18 : 1-7 